\title{
Static Bending Loading Diagram in Wood
}

\author{
Tiago Hendrigo de Almeida ${ }^{1}$, Diego Henrique de Almeida ${ }^{2}$, \\ André Luis Christoforo ${ }^{2, *}$, Francisco Antonio Rocco Lahr ${ }^{3}$
}

\author{
${ }^{1}$ Department of Science and Materials Engineering, São Paulo University (EESC/USP), São Carlos, Brazil \\ ${ }^{2}$ Centre for Innovation and Technology in Composites - CITeC, Department of Civil Engineering (DECiv), \\ Federal University of São Carlos, São Carlos, Brazil \\ ${ }^{3}$ Department of Structural Engineering, São Paulo University (EESC/USP), São Carlos, Brazil
}

\begin{abstract}
Three-point static bending test according to the code NBR 7190/1997 allows to determine two wood properties: modulus of elasticity and conventional value of Strength. According to this code, determination of the modulus of elasticity must be through loading cycle occurring between $10 \%$ and $50 \%$ of the rupture of an estimation sample. However, it is usual to perform these cycles using L/200 and L/1000 deflection parameters, where $\mathrm{L}$ is the value of the length. Given this, it becomes necessary to evaluate the loading diagrams in the bending tests to find out the existence of patterns on it. This work aimed to analyze the loading curves in the three-point static bending tests in eighteen free of defect samples, of square section and L/h equal to fourteen, made with Simarouba amara Aubl. wood at 12\% moisture content. Analysis was focused on the force percentages applied (in relation to the rupture) for these samples present $\mathrm{L} / 1000, \mathrm{~L} / 200$ and $\mathrm{L} / 100$ deflection values, and the elastic limit (LE) (in relation to the rupture) was determined. Results of the mean percentages were $4.11 \%, 22.51 \%, 44.63 \%$ and $78.51 \%$ for $\mathrm{L} / 1000, \mathrm{~L} / 200, \mathrm{~L} / 100$ and LE, respectively. According to results, it was possible to conclude that there is a pattern of samples behaviors subjected to three-points static bending, making possible to use deflection parameters in the loading cycles.
\end{abstract}

Keywords Loading cycle, Static bending, Wood

\section{Introduction}

Wood is a renewable source material with important role in the furniture, paper and pulp, and construction industries [1-4]. In this last segment, wood can be used in frames, building components and structural elements such as pillars, trusses and beams $[6,7]$. Beams are horizontal structural elements, subject to loads that generate stresses in the static bending (traction and compression). Thus, for better use of resources (wood, time and labor), it is necessary that the structural design is very well performed, which goes through the process of determining its physical and mechanical properties [8-10].

In Brazil, such determination must be made in accordance with the Brazilian Association of Technical Standards (ABNT) in its code ABNT NBR 7190: 1997 "Wood Structures Design". In Appendix B of this code, "Determination of Wood Properties for Structural Design", all procedures for carrying out tests are described. One of these tests is the static bending test for determination of the modulus of elasticity and the conventional strength value [11].

* Corresponding author:

alchristoforo@gmail.com (André Luis Christoforo)

Published online at http://journal.sapub.org/ijme

Copyright (C) 2018 Scientific \& Academic Publishing. All Rights Reserved
For modulus of elasticity determination, a loading cycle is performed, which must take place between $50 \%$ and $10 \%$ of the rupture force of a test sample used as an estimate and, after that, test at least 12 samples.

In the daily routine of mechanical properties of wood laboratories based on the Brazilian code, it is common to use a deflection parameter in the loading cycle to determine the modulus of elasticity (or stiffness) in bending. It is because this way it is possible to do the cycle without the test sample for estimation of rupture. This practice also speeds up the characterization of wood in general, as well as structural pieces presenting larger dimensions. Deflection parameters commonly used are L/200 and L/500, where L is the length.

In this respect, it is extremely important to know if these deflection parameters are compatible to the procedure described in the Brazilian code, and in addition, create a way for better use the code making the process of wood characterization faster.

This research aimed to verify the existence of a pattern between the deflection presented by the sample, due to the portion of exerted force on it (in relation to the rupture of the same sample) by the analysis of the loading diagrams of wood (for the modulus of elasticity determination), and them, determine a procedure to use the deflection as a parameter of loading cycle, showing more assertive values of applied percentage of force. 


\section{Material and Methods}

Based on the recommendations of Almeida [12], 18 samples with nominal dimensions $20 \times 20 \times 320 \mathrm{~mm}$ were made using wood with moisture content around $12 \%$ (equilibrium moisture), and the largest dimension of the sample in the parallel to the grain direction.

As the focus of the present research is the study of the test method, a homogeneous batch of wood was selected from a certified forest area. The tropical specie of wood Caixeta (Simarouba amara Aubl.) showed density at 12\% moisture content around $0.40 \mathrm{~g} / \mathrm{cm}^{3}$ and according to the Brazilian code, it was belonging to the Strength Class C20 of the dicotyledons [12-14].

When referring to the static bending sample recommended by the Brazilian code, it has a length/height ratio of 21 . However, the test specimens used in this research had this ratio equal to 14 , due to the equipment used in the tests, EMIC Universal Testing Machine, not be able to perform tests in samples larger than $320 \mathrm{~mm}$ (Figure 1).

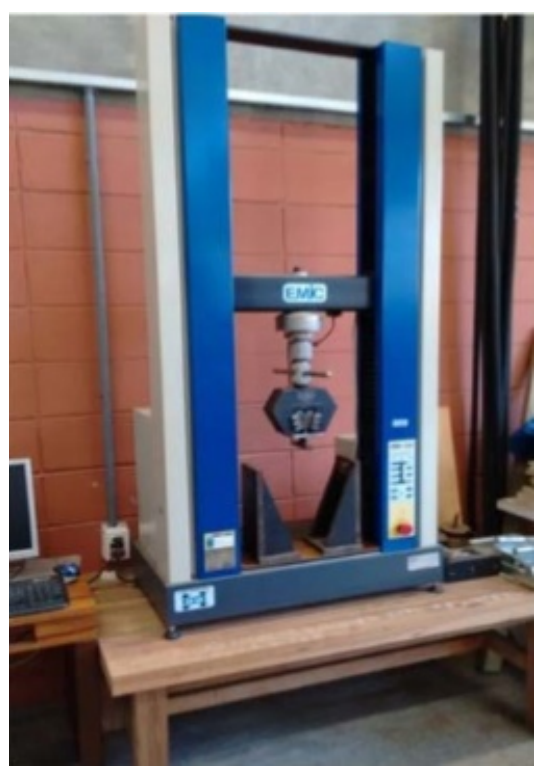

(a)

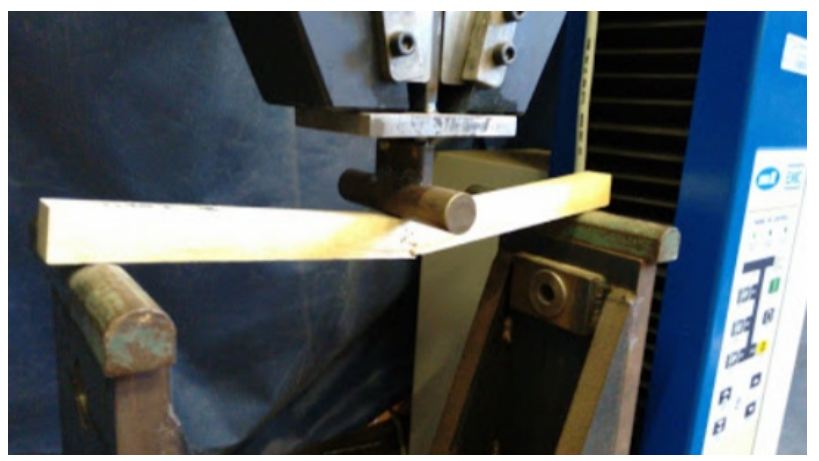

(b)

Figure 1. Static bending test: (a) EMIC Universal Testing Machine; (b) Sample of Caixeta wood
On the other hand, since all work was carried out by determining the stress exerted on the sample in relation to the rupture, and the strength of the sample is independent of the value of the length (L) adopted in the test (being a characteristic of the sample), the results shown in this research can be adapted for more general studies.

Through the EMIC Universal Testing Machine software, the graphics force vs. deflection can be built, and it is possible to set the loading diagram of the static bending test for each sample, taking force applied and deflection values in the middle of the length. For carrying out the tests, the loading speed adopted was $5 \mathrm{~mm}$ of deflection per minute.

Parameters of loading diagram determined in this research were the percentages of applied force (related to rupture) for the sample presents deflection value equal to L/100, L/200 and $\mathrm{L} / 1000$ (being $\mathrm{L}=280 \mathrm{~mm}$ ), ie $2.80 \mathrm{~mm}, 1.40 \mathrm{~mm}$ and $0.28 \mathrm{~mm}$, respectively, as well as the elastic limit (LE) of each sample.

Using the deflection parameters L/100, L/200 and L/1000, it was possible to know the force required for the samples present such deflection and thus relate them to their respective ruptures. For determination of the exact deflection at $10 \%$ and $50 \%$ of the rupture, regression models (linear, quadratic, exponential and geometric) were proposed to determine the denominator $k$ of the $\mathrm{L} / k$ parameter as a function of the percentage of rupture (CR) that shows this deflection.

\section{Results and Discussion}

Figure 2 shows the loading diagrams for 18 samples of Caixeta wood in static bending test, as well as the deflection values for $\mathrm{L} / 1000, \mathrm{~L} / 200$ and $\mathrm{L} / 100$.

From the analysis of the loading diagrams and using the deflection parameters L/100, L/200 and L/1000, it was possible to verify the necessary force to the samples present such deflections and, thus, to relate them with the respective rupture. Table 1 shows the mean values $\left(\mathrm{x}_{\mathrm{m}}\right)$, maximum (Max), minimum (Min) and coefficients of variation (CV) for $\% \mathrm{~L} / 100, \% \mathrm{~L} / 200$ and $\% \mathrm{~L} / 1000$, which represent percentages of applied force, in relation to the rupture, to the deflections reach the $\mathrm{L} / 100, \mathrm{~L} / 200$ and L/1000 values, respectively. \% LE means the maximum percentage of force applied, in relation to the rupture, for the sample presents the linear aspect in the loading diagram.

According to Table 1, the average force percentages, in relation to the rupture, for the samples present $\mathrm{L} / 100, \mathrm{~L} / 200$ and L/1000 deflection were 44.63, 22.51 and $4.11 \%$, respectively. It should be noted that the coefficients of variation of these results were less than $10 \%$ reaffirming their accuracy. The average elastic limit obtained was $78.51 \%$ of the rupture. 


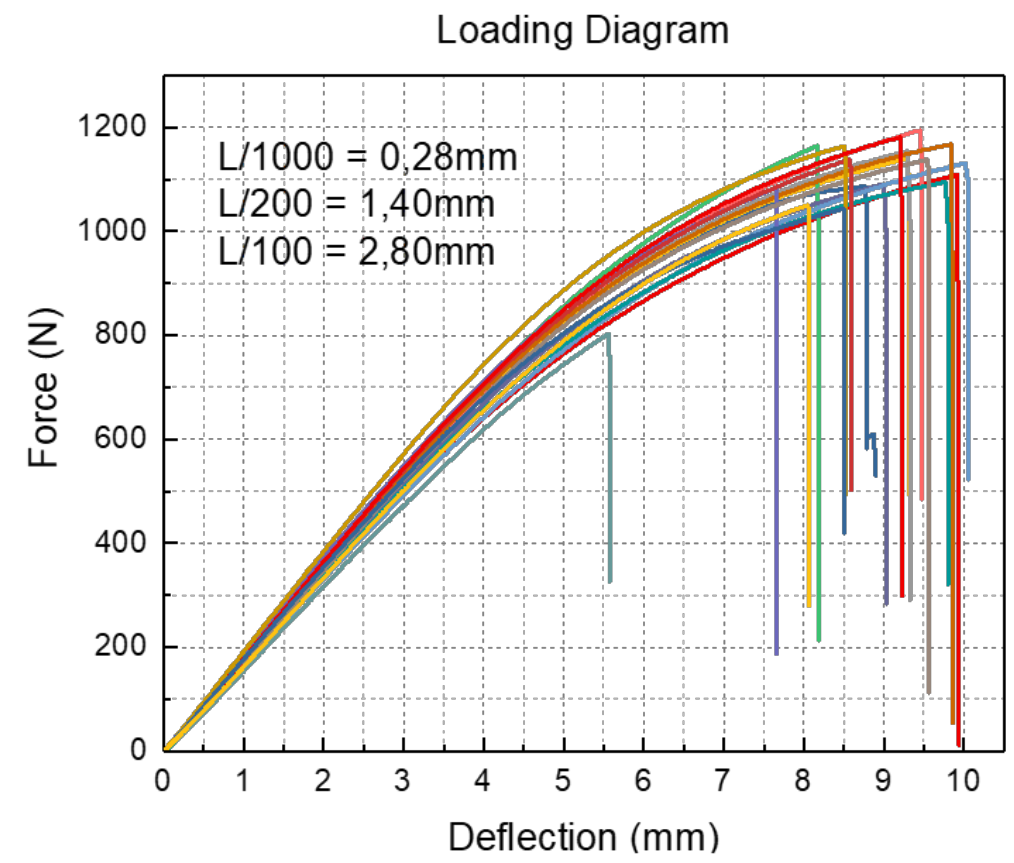

Figure 2. Loading curves in Static bending test for 18 samples of Caixeta

Table 1. Summary of results for percentages of force to reach all deflection values

\begin{tabular}{ccccc}
\hline Statistics & \%L/100 (\%) & $\mathbf{\% L / 2 0 0 ( \% )}$ & $\mathbf{\% L / 1 0 0 0}(\mathbf{\%})$ & $\mathbf{\% L E ~ ( \% ) ~}$ \\
\hline $\mathrm{x}_{\mathrm{m}}$ & 44.63 & 22.51 & 4.11 & 78.51 \\
$\mathrm{CV}(\%)$ & 7.40 & 7.66 & 9.51 & 8.49 \\
Min & 40.26 & 20.26 & 3.60 & 72.26 \\
Max & 54.78 & 27.45 & 4.90 & 97.43 \\
\hline
\end{tabular}

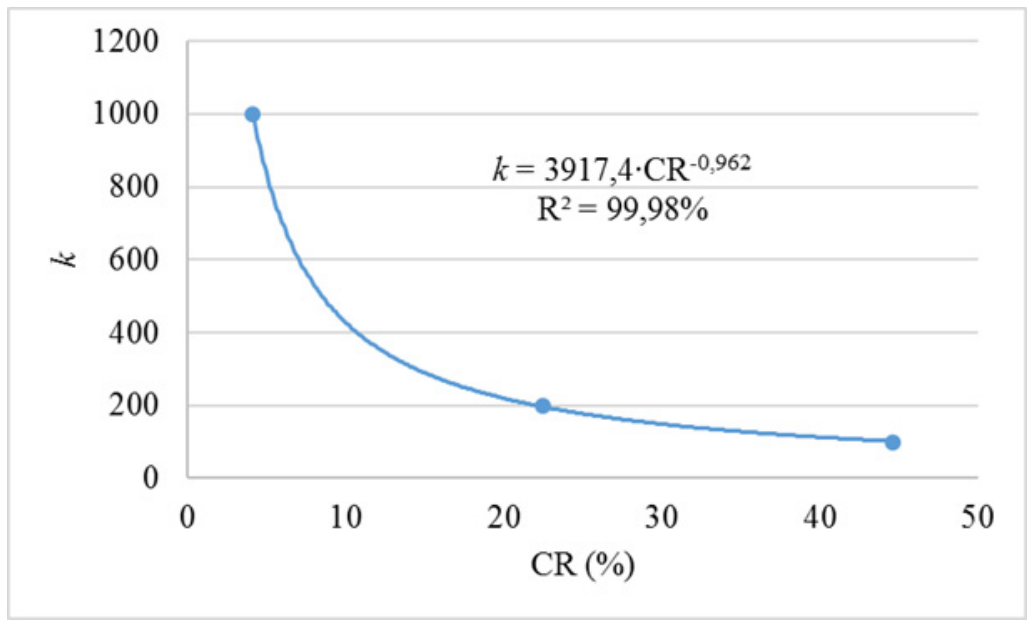

Figure 3. Static bending test: (a) EMIC Universal Testing Machine; (b) Caixeta sample

Geometric regression model was the one that presented the best coefficient of determination $\left(\mathrm{R}^{2}\right)$ for estimating the $k$ value of the parameter L/k (Figure 3), as a function of the percentage of the rupture force. The function $k=3917.4 \cdot \mathrm{CR}^{-0.962}$ presented a coefficient of determination equal to $99.98 \%$, where CR denotes the percentage of the applied force in relation to the rupture.
This function described by the geometric regression model allows to determine the exact deflection when the samples are subjected to forces of $10 \%$ and $50 \%$ of the rupture. Using the diagram function of Figure 3, the deflection values found were equal to $\mathrm{L} / 91$ and $\mathrm{L} / 428$ to forces equal to $10 \%$ and $50 \%$ of the rupture, respectively. 


\section{Conclusions}

According to the procedures adopted, as well as the results obtained using Caixeta wood, it was possible to perceive the existence of a pattern in the loading diagrams of the samples subjected to static bending, resulting in the existence of a force pattern (relation to the rupture), for deflection values presented by the samples tested. Therefore, the use of deflection parameters at the time of the loading cycles to determine the modulus of elasticity, instead of the use of an estimation test (force parameter), seems to guarantee the accuracy of the modulus of elasticity determination in bending. Authors suggest the expansion of the research in this sense, considering other species, as well as other cross sections (not square).

\section{REFERENCES}

[1] ALMEIDA, T. H. Estudo da estabilidade dimensional de madeiras tropicais brasileiras. 2015. 102 f. Dissertação (Mestrado em Ciência e Engenharia de Materiais) - Escola de Engenharia de São Carlos, Universidade de São Paulo, São Carlos, 2015.

[2] ANDRADE JUNIOR, J. R. et al. Avaliação das estruturas de cobertura em madeira de um galpão de estoques de produtos químicos. Ambiente Construído, v.14, n.3, p.75-85, 2014.

[3] TAKESHITA, S.; ANDRADE, A.; JANKOWSKY, I. P. Planejamento estratégico para o setor de pisos de madeira. Floresta e Ambiente, v.18, n.3, p.237-242, 2011. Doi: 10.4322/floram.2011.043.

[4] SILVA, D. A. L. et al. Life cycle assessment of offset paper production in Brazil: hotspots and cleaner production alternatives. Journal of Cleaner Production, v.93, p.222-233, 2015. Doi: 10.1016/j.jclepro.2015.01.030.

[5] CALIL JUNIOR, C.; LAHR, F. A. R.; DIAS, A. A. Dimensionamento de elementos estruturais de madeira. Barueri: Manole, 2003.

[6] GARCIA, D. R. J. et al. Alternative woods in framework arc for pedestrian footbridge. International Journal of
Materials Engineering, v.7, n.4, p.68-76, 2011. Doi: 10.5923/j.ijme.20170704.02.

[7] SCAliante, R. M. Pontes em vigas e tabuleiros em painéis de Madeira Laminada Colada (MLC). 2014. 235 f. Dissertação (Mestrado em Engenharia Civil - Estruturas) Escola de Engenharia de São Carlos, Departamento de Engenharia de Estruturas, Universidade de São Paulo, São Carlos, 2014

[8] ALMEIDA, D. H. et al. Caracterização completa da madeira da espécie amazônica Paricá (Schizolobium amazonicum HERB) em peças de dimensões estruturais. Revista Árvore, v.37, n.6, p.1175-1181, 2013.

[9] CHRISTOFORO, A. L. et al. Physico-mechanical characterization of the Anadenanthera colubrina Wood specie. Engenharia Agrícola, v.37, n.2, p.376-384, 2017. Doi: 10.1590/1809-4430- Eng.Agric.v37n2p376-384/2017.

[10] LAHR, F. A. R. et al. Avaliação das propriedades físicas e mecânicas de madeiras de Jatobá (Hymenaea stilbocarpa Hayne) com diferentes teores de umidade e extraídas de regiões distintas. Revista Árvore, v.40, n.1, p.147-154, 2016. Doi: 10.1590/0100-67622016000100016.

[11] ASSOCIAÇÃO BRASILEIRA DE NORMAS TÉCNICAS. ABNT NBR 7190. Projeto de estruturas de madeira. Rio de Janeiro: ABNT, 1997.

[12] ALMEIDA, D. H. et al. Estimativa de propriedades de resistência e rigidez na flexão estática através de parâmetros colorimétricos da madeira. In: CONGRESSO BRASILEIRO DE CIÊNCIA E TECNOLOGIA DA MADEIRA, 2017, Florianópolis. Anais... Florianópolis, CBCTEM, 2017. online.

[13] STANGERLin, D. M. et al. Dureza Rockwell da madeira de três espécies amazônicas submetidas a ensaios de apodrecimento acelerado. Ciência Rural, v.43, n.4, p.623-630, 2013

[14] TELES, R. F. Ensaios não destrutivos para avaliar o desempenho de madeiras Amazônicas tratadas quimicamente. 2014. 208 f. Dissertação (Mestrado em Ciências Florestais) - Faculdade de Tecnologia, Departamento de Engenharia Florestal, Universidade de Brasília, Brasília, 2014. 